\title{
УРОЖАЙНІСТЬ І ЯКІСТЬ НАСІННЯ ГОРОХУ, НУТУ, СОЇ ЗА ВПЛИВУ ЗАБУР'ЯНЕНОСТІ, ІНОКУЛЯЦІЇ ТА ГЕРБІЦИДУ
}

Гутянський Р.А., Ільченко Н.К., Шелякіна Т.А., Посилаєва О.О. Інститут рослинництва ім. В.Я. Юр`єва НААН, Україна

Установлено, що гербіцид Пульсар $40 є$ найбільш придатним у посівах сої, а найменш - нуту. Його післясходове застосування в посівах гороху і нуту на фоні без інокуляції доказово знижувало масу 1000 насінин цих культур. Найбільший приріст урожайності від інокуляції насіння препаратом Ризобофіт виявлено на нуті. Не виявлено доказового впливу комплексу досліджуваних факторів на вміст білка й олії в насінні гороху, нуту і сої.

Ключові слова: горох, нут, соя, інокулячія, бур'ян, гербіцид, урожайність, маса 1000 насінин, білок, олія

Вступ. Останніми роками роль гороху, нуту та сої в агропромисловому комплексі України істотно зросла. Це пов'язано з тим, що вони мають дуже різні вимоги до метеорологічних умов, різну тривалість вегетаційного періоду та господарську цінність. Така різниця між цими зернобобовими культурами, особливо за умов змін клімату в бік потепління, дає можливість компенсувати втрати цінного рослинного білка та інших якісних показників $[1,2]$. Виходячи 3 цього, вивчення особливостей формування врожайності та якості насіння гороху, нуту і сої за різних технологічних прийомів вирощування $є$ досить актуальним і важливим завданням.

Аналіз літературних джерел, постановка проблеми. Врожайність і якість насіння зернобобових культур залежить від багатьох факторів. Установлено, що найбільший вміст білка в насінні гороху мають листочкові сорти, а максимальний урожай забезпечують сорти безлисточкового морфотипу. Найбільший вплив на формування рівня збору білка має фактор рік - 47,9 \% у листочкових сортів та 36,5 \% у безлисточкових, фактор фон живлення 33,0 \% та 36,5 \% відповідно, сорт 19,1 \% та 26,7 \% відповідно. За внесення добрив значно підвищується врожайність та якість насіння гороху [3].

За вирощування гороху із внесенням азотних добрив за схемою $\mathrm{N}_{30}$ до сівби $+\mathrm{N}_{30} \mathrm{y}$ фазі бутонізації, $\mathrm{P}_{60} \mathrm{~K}_{60}$ до сівби на фоні інтенсивної системи захисту рослин та обробки насіння перед сівбою стимулятором росту Емістим C i активними штамами бульбочкових бактерій Rh. leguminosarum формуються найвищі показники врожайності, вмісту сирого протеїну та його збору [4].

Інокуляція насіння гороху Ризоторфіном у нормі 300 г/га забезпечує збільшення вмісту протеїну в насінні на 0,2-0,5 \%, а при триразовому позакореневому внесенні макроі мікродобрив Еколіст вміст сирого протеїну збільшується на 0,3-0,6 \% [5].

Показники якості насіння нуту, особливо вміст білка, залежать від генетичних особливостей сорту та дії зовнішніх факторів $[6,7]$. Також вміст білка в насінні нуту збільшується під впливом інокуляції насіння Нітрагіном залежно від сорту на 1,09-2,85 \%. За вмістом олії різниця в 0,5 \% знаходилась у межах помилки досліду [8]. Підвищити рівень білковості можливо шляхом видалення насіннєвих оболонок (лущення) [9].

Застосування мінеральних добрив та проведення інокуляції насіння нуту азотфіксувальними бактеріями істотно впливає на фізичні показники якості зерна: масу натурну, крупність, вирівняність. Найбільший вплив на вміст білка й олії в насінні нуту мають азотні добрива, а також внесення дефекату та проведення інокуляції насіння.

(C) Р.А.Гутянський, Н.К. Ільченко, Т.А. Шелякіна, О.О. Посилаєва. 2018.

ISSN 1026-9959. Селекція і насінництво. 2018. Випуск 113. 
У цілому найкращі показники якості зерна нуту забезпечує проведення вапнування грунту або застосування молібденових добрив у поєднанні з внесенням фосфорних і калійних добрив під зяблевий обробіток грунту в нормі по 60 кг/га д. р. і стартової дози азотних добрив $\left(\mathrm{N}_{30}\right)$ під передпосівну культивацію [10].

Маточний колоїдний розчин комплексу (Fe, Mn, $\mathrm{Mo}, \mathrm{Co}, \mathrm{Cu}, \mathrm{Zn}, \mathrm{Ag}$ ) наночастинок металів потрійної концентрації (3 мл/л) сприяє поліпшенню посівних якостей насіння сортів нуту [11].

Попередніми дослідженнями в забур'янених посівах сої виявлено тенденцію до зниження вмісту білка в насінні сортів з тривалішим вегетаційним періодом. Якщо розмістити сорти сої в порядку зростання тривалості вегетаційного періоду (Устя, Романтика, Фея - 101, 110, 121 діб відповідно), то вміст білка досягав 41,6; 40,1; 39,6 \% [12]. Також не було встановлено негативного впливу гербіцидів Харнес, Півот, Базагран, Хармоні, Фюзілад Форте, Пульсар, Фабіан та їх бакових сумішей на вміст білка й олії в насінні сої. Виключенням стали варіанти з внесенням бакових сумішей гербіцидів Харнес + Півот (2,0 л/га $+0,5$ л/га; 2,0 л/га + 0,67 л/га), де відбулось незначне доказове зниження вмісту олії в насінні сої від 0,6 \% до 0,7 \% порівняно з контролем (з бур“янами без гербіцидів) [13].

Вищий вміст білка в насінні сої за оранки як на природному фоні, так і при внесенні 40 кг/га д. p. мінеральних добрив отримано за інокуляції насіння Ризогуміном у комбінації 3 регулятором росту Біолан $-41,57$ \% та 42,47 \% відповідно при 40,69 \% у абсолютному контролі. За дискування максимальним цей показник був на фоні без внесення добрив при застосуванні цих же біопрепаратів - 42,00 \%, що на 3,47 \% вище порівняно 3 контролем [14]. Іншими дослідженнями показано, що інокуляція насіння високоефективним штамом B. japonicum 71т (УКМ В-6035) сприяє формуванню активного симбіотичного апарату, підвищенню вмісту протеїну в зеленій масі та збільшенню збору протеїну з гектара [15].

Чорна В.М. відмічає, що найвищі показники маси 1000 насінин та врожайності насіння сортів сої КиВін, Княжна та Монада формувались за інокуляції насіння бактеріальним препаратом Оптімайз та обробки посівів у фазі бутонізації хлормекватхлоридом [16].

Мета і задачі досліджень. Установити комплексний вплив інокуляції насіння та різних строків внесення гербіциду Пульсар 40 на врожайність і якість насіння гороху, нуту і сої в умовах східної частини Лісостепу України.

Для досягнення поставленої мети було закладено трьохфакторний дослід, в якому першим фактором була культура (горох, нут, соя), другим - варіант обробки насіння (без інокуляції, з інокуляцією), а третім - варіант захисту від бур'янів (контроль; Пульсар 40, 0,8 л/га до сходів; Пульсар 40, 0,8 л/га після сходів).

Матеріал і методика. Дослідження проводили впродовж 2013-2015 рр. в умовах східної частини Лісостепу України (Харківська область). Грунт - чорнозем типовий важкосуглинковий. Попередник - ячмінь ярий. Добрив не застосовували. Основну підготовку грунту проводили за типом поліпшеного зябу. Передпосівний обробіток під горох і нут полягав у проведенні ранньовесняного боронування та однієї культивації, а під сою - ранньовесняного боронування і двох культивацій. Обробку насіння зернобобових культур проводили в день сівби препаратом Ризобофіт (штами бактерій Rhizobium і Bradyrhizobium, титр - 0,5-1,0 млрд./г) [17]. Сівбу гороху і нуту проводили в квітні, а сої - в травні. Вихідним матеріалом були сорти гороху Оплот, нуту Тріумф та сої Романтика. Ширина міжрядь - 15 см. Відразу після сівби проводили післяпосівне прикочування грунту з наступним внесенням гербіциду Пульсар 40 (діюча речовина - імазамокс, 40 г/л) [17] у відповідності зі схемою досліду. В період вегетації гербіцид Пульсар 40 застосовували у посівах гороху у фазі 5-6 справжніх листків, нуту - 2-3 гілочок, сої - в період формування примордіальних листків. Гербіцид вносили за допомогою ранцевого обприскувача 3 витратою робочої рідини 300 л/га. Контроль - забур'янений посів (без застосування гербіциду). Площа облікової ділянки - 36,0 м². Повторення триразове. Збирали зернобобові культури селекційним комбайном «Sampo-130». Лабораторні аналізи з визначення вмісту білка й олії в насінні гороху, нуту та сої проводили фахівці лабораторії генетики, біотехнології та якості Інституту рослинництва ім. В.Я. Юр‘єва НААН. 
Обговорення результатів. Гербіцид Пульсар 40, внесений у досходовий період, виявив високу селективність до рослин гороху і сої, а недостатню - до нуту. На рослинах гороху і сої післясходове застосування препарату викликало середнє і слабке фітотоксичне пригнічення відповідно, а нуту - значне.

Найбільша кількість і маса азотфіксуючих бульбочок формувалась на сої, а найменша - у гороху. Помітне збільшення цих показників від інокуляції насіння виявлено на нуті, який вперше увели в експериментальну сівозміну, а взагалі не виявлено - на сої. На горохові інокуляція насіння сприяла збільшенню лише кількості бульбочок.

Гербіцид Пульсар 40 у цілому краще контролював дводольні малорічні бур“яни, ніж злакові однорічні. Також виявлено, що на горохові та сої препарат більше контролював злакові однорічні бур'яни за внесення після сходів, ніж до сходів. Водночас у посівах гороху і нуту препарат краще контролював дводольні малорічні бур“яни за внесення до сходів, а в посівах сої - після сходів. Загальну забур“яненість у посівах гороху і сої гербіцид контролював краще, ніж у посівах нуту.

Рівень урожайності гороху, нуту і сої залежав, по-перше, від метеорологічних умов року, які складались протягом вегетації окремої культури, а по-друге і по-третє, - від рівня забур“яненості посіву і передпосівної інокуляції насіння (табл. 1).

Таблиця 1

Урожайність та маса 1000 насінин зернобобових культур залежно від інокуляції та дії гербіциду, 2013-2015 рр.

\begin{tabular}{|c|c|c|c|c|}
\hline \multicolumn{3}{|c|}{ Варіант } & $\begin{array}{c}\text { Урожайність, } \\
\text { т/га }\end{array}$ & $\begin{array}{l}\text { Маса } 1000 \text { на- } \\
\text { сінин, г }\end{array}$ \\
\hline \multirow{6}{*}{ Горох } & \multirow{3}{*}{ без інокуляції } & контроль & 0,93 & 255 \\
\hline & & Пульсар 40, до сходів & 1,02 & 264 \\
\hline & & Пульсар 40, після сходів & 0,94 & 202 \\
\hline & \multirow{3}{*}{ з інокуляцією } & контроль & 0,95 & 204 \\
\hline & & Пульсар 40, до сходів & 1,10 & 207 \\
\hline & & Пульсар 40, після сходів & 0,95 & 192 \\
\hline \multirow{6}{*}{ Нут } & \multirow{3}{*}{ без інокуляції } & контроль & 1,43 & 275 \\
\hline & & Пульсар 40, до сходів & 1,41 & 246 \\
\hline & & Пульсар 40, після сходів & 0,65 & 228 \\
\hline & \multirow{3}{*}{ з інокуляцією } & контроль & 1,46 & 257 \\
\hline & & Пульсар 40, до сходів & 1,53 & 265 \\
\hline & & Пульсар 40, після сходів & 0,72 & 267 \\
\hline \multirow{6}{*}{ Соя } & \multirow{3}{*}{ без інокуляції } & контроль & 0,92 & 130 \\
\hline & & Пульсар 40, до сходів & 1,29 & 141 \\
\hline & & Пульсар 40, після сходів & 1,32 & 142 \\
\hline & \multirow{3}{*}{ з інокуляцією } & контроль & 0,87 & 133 \\
\hline & & Пульсар 40, до сходів & 1,35 & 144 \\
\hline & & Пульсар 40, після сходів & 1,37 & 143 \\
\hline \multicolumn{3}{|c|}{ HІР $_{05}$ для фактора А (культура) } & 0,15 & 28 \\
\hline \multicolumn{3}{|c|}{ НІР 05 для фактора В (інокуляція) } & 0,12 & 23 \\
\hline \multicolumn{3}{|c|}{ HIP 05 для фактора С (гербіцид) } & 0,15 & 28 \\
\hline \multicolumn{3}{|c|}{$\mathrm{HIP}_{05}$ для факторів $\mathrm{AB}$} & 0,21 & 40 \\
\hline \multicolumn{3}{|c|}{$\mathrm{HIP}_{05}$ для факторів $\mathrm{AC}$} & 0,26 & 49 \\
\hline \multicolumn{3}{|c|}{$\mathrm{HIP}_{05}$ для факторів ВC } & 0,21 & 40 \\
\hline \multicolumn{3}{|c|}{$\mathrm{HIP}_{05}$ для факторів АBC } & 0,37 & 69 \\
\hline
\end{tabular}

Установлено, що на рівень урожайності гороху і нуту найбільш впливали метеорологічні умови року, які складались у квітні-червні. Так, у 2013 р. вони були найменш сприятливими для формування врожайності нуту і особливо гороху. Причиною цьому ста- 
ла висока середньодобова температура повітря і кількість опадів, менша за норму. Найбільший рівень урожайності ці зернобобові культури сформували в 2015 р. У 2014 р., не дивлячись на більшу кількість опадів порівняно з 2015 р., отримано меншу врожайність гороху і нуту. Це було пов 'язано з аномально високою середньодобовою температурою повітря в кінці травня - на початку червня 2014 р.

Урожайність сої, насамперед, залежала від метеорологічних умов у літній період (від I декади червня по III декаду серпня включно). Так, у 2013 р. отримано найменший рівень урожайності сої, що було обумовлено низькою кількістю опадів і високою середньодобовою температурою повітря в зазначений період. У 2014 р. отримано дещо вищий рівень урожайності сої, ніж у 2013 р. У 2015 р., не дивлячись на найменшу кількістю опадів за наведений період і високу середньодобову температуру повітря, отримано врожайність сої на рівні 2014 р., що було пов'язано з інтенсивними опадами в кінці червня, коли в сої проходили фази цвітіння і формування бобів.

Отже, за метеорологічними умовами року найбільш сприятливим для формування врожайності зернобобових культур виявився 2015 р., а найменш сприятливим - 2013 р. Так, у середньому врожайність гороху, нуту і сої в 2013 р. становила 0,48; 0,80 і 0,94 т/га відповідно, а в 2014 р. та 2015 р. - 0,73; 0,90 і 1,05 т/га та 1,74; 1,90 і 1,57 т/га відповідно.

Установлено, що найбільшу врожайність у забур'янених контролях формував нут. Так, середня врожайність гороху, нуту і сої в контролях становила 0,94; 1,45 і 0,90 т/га відповідно. Зауважимо, що середня сира маса бур“янів у посівах нуту на час збирання врожаю

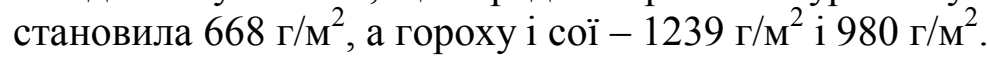

Аналіз урожайності також засвідчив, що дуже сильна фітотоксична дія гербіциду Пульсар 40 на молоді рослини нуту в період вегетації спричинила недобір урожайності цієї культури. Так, порівняно з контролем застосування цього гербіциду в післясходовий період на фоні без інокуляції викликало у середньому недобір урожайності нуту 0,78 т/га, а 3 інокуляцією - 0,74 т/га. За досходового застосування гербіциду в посівах гороху не спостерігали його фітотоксичної дії на культурні рослини, а післясходового - спостерігали (певний час). Так, порівняно $з$ досходовим внесенням гербіциду післясходове його застосування на фоні без інокуляції і з інокуляцією призводило до зменшення врожайності гороху на 0,08 т/га і 0,15 т/га відповідно. Врожайність сої в цілому залежала від дії гербіциду на бур“яни за різних строків внесення. 3 огляду на це у середньому більший приріст урожайності цієї культури, порівняно з контролем, отримано за післясходового внесення гербіциду (на фоні без інокуляції та з інокуляцією 0,40 т/га і 0,50 т/га відповідно), а дещо менший (на фоні без інокуляції та з інокуляцією 0,37 т/га і 0,48 т/га відповідно) - за досходового внесення.

Приріст урожайності зернобобових культур від інокуляції виявлено майже на всіх варіантах досліду. Особливо помітним він був на фоні досходового внесення гербіциду Пульсар 40 у посівах усіх зернобобових культур. У цілому найбільшим приріст урожайності від інокуляції був у нуту (контроль - 0,03 т/га; Пульсар 40, 0,8 л/га до сходів - 0,12 т/га; Пульсар 40, 0,8 л/га після сходів - 0,07 т/га).

Аналіз окремих морфологічних ознак культурних рослин показав, що найвищою серед зернобобових культур була соя (81-85 см), а найнижчим - горох (40-43 см). У цілому за досходового внесення гербіциду Пульсар 40 установлено незначну тенденцію до зростання висоти рослин зернобобових культур порівняно з іншими варіантами. Післясходове застосування гербіциду, яке викликало значне фітотоксичне пригнічення рослин нуту, зумовило зменшення висоти рослин цієї культури (понад $20 \mathrm{~cm}$ ). Післясходове застосування гербіциду в посівах усіх зернобобових культур призводило до зниження висоти прикріплення нижнього боба. Не виявлено впливу інокуляції насіння на морфологічні ознаки рослин зернобобових культур.

Аналізом ознак продуктивності зернобобових культур установлено, що найменшими були показники у гороху - кількість продуктивних вузлів та бобів на одній рослині та кількість і маса насіння з рослини; у нуту - кількість бобів у продуктивному вузлі та насіння в бобі; у сої - маса 1000 насінин. Горох, крім зазначених ознак продуктивності, також форму- 
вав найменшу масу однієї рослини. У цілому зростання більшості цих показників на фоні 3 інокуляцією порівняно з фоном без інокуляції виявлено лише за внесення гербіциду Пульсар 40 до сходів на нуті. На інших варіантах з інокуляцією встановлено зниження рівня показників порівняно з фоном без інокуляції. Це пов'язано, насамперед, з більшим рівнем забур“яненості зернобобових культур на фоні з інокуляцією порівняно з фоном без інокуляції. На фоні без інокуляції найвищим рівень прояву ознак продуктивності у гороху сформувався за використання гербіциду в досходовий період, а сої - в післясходовий.

Більш детальний аналіз формування маси 1000 насінин зернобобовими культурами встановив доказове зниження цього показника в гороху і нуту на фоні без інокуляції під впливом післясходового застосування гербіциду Пульсар 40 (на 53 г і 47 г відповідно) порівняно з контролем. Також виявлено тенденцію до збільшення маси 1000 насінин у сої під вПливом обох строків застосування гербіциду Пульсар 40.

Вміст білка й олії в насінні зернобобових культур значно різнився (табл. 2). Найбільшими ці показники були в насінні сої. Так, у насінні гороху, нуту і сої в середньому вміст білка становив 21,5; 21,1 і 38,4 \% відповідно, а олії - 3,2; 6,5 і 17,6 \%.

Таблиця 2

Вміст і збір білка, олії з насіння зернобобових культур, вирощеного за дії інокуляції та гербіциду, 2013-2015 рр.

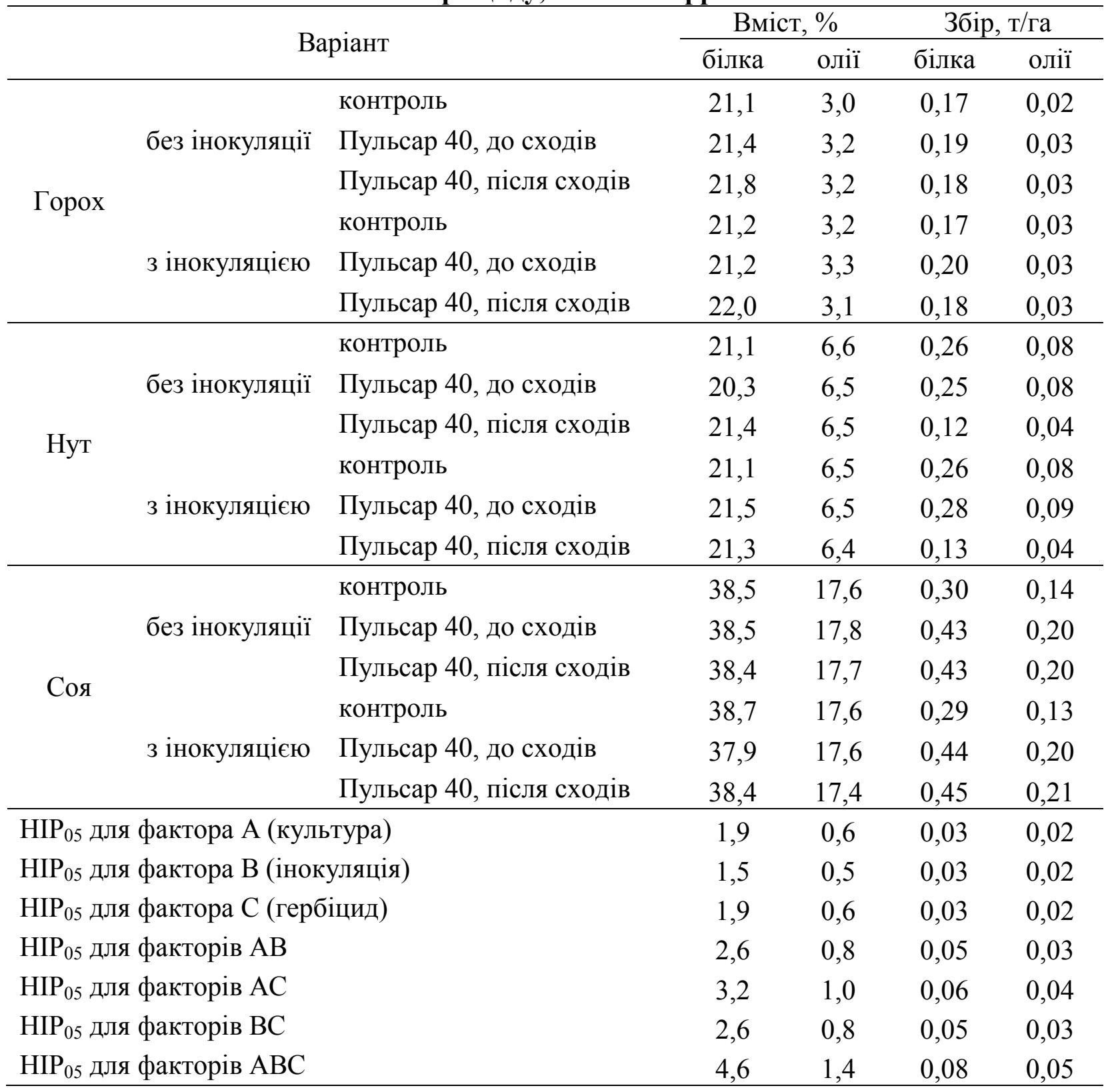


Також істотно різнився вміст білка й олії в насінні гороху, нуту і сої в окремі роки досліджень. Так, у середньому найбільшим вміст білка в насінні гороху, нуту і сої був у 2013 p. (22,6 \%), 2015 p. (22,4 \%) і 2014 p. (43,8 \%), а найменшим - у 2014 p. (20,4 \%), 2013 p. $(20,0 \%)$ і 2013 p. (34,0 \%). У середньому найбільшим вміст олії в насінні гороху, нуту і сої був у 2014 р. (4,0 \%), 2013 p. (8,1\%) і 2013 р. (17,9\%), а найменшим - у 2015 р. (1,6 \%), 2014 p. $(5,5 \%)$ i 2015 p. $(17,3 \%)$.

У середньому за три роки досліджень виявлено тенденцію до збільшення вмісту білка в насінні гороху за внесення гербіциду Пульсар 40 у період вегетації. Так, порівняно 3 контролем збільшення цього показника на фоні з інокуляцією і без інокуляції становило 0,7 \% і 0,8 \% відповідно. Водночас досходове застосування цього гербіциду на фоні без інокуляції нуту і на фоні з інокуляцією сої зумовило помітне зниження вмісту білка в насінні цих культур, порівняно з іншими варіантами досліду. Не виявлено істотного впливу комплексу досліджуваних факторів на вміст олії в насінні гороху, нуту і сої.

Найбільший збір білка й олії з одиниці площі виявлено на сої, а найменший - на горохові. Так, збір білка $з$ насіння гороху, нуту і сої в середньому за три роки досліджень становив 0,18; 0,22 і 0,34 т/га відповідно, а збір олії - 0,03; 0,07 і 0,18 т/га. Найбільшими ці показники були в сприятливому для формування врожайності зернобобових культур 2015 році, де середній збір білка з насіння гороху, нуту і сої становив 0,32; 0,37 і 0,51 т/га відповідно, а збір олії-0,02; 0,10 і 0,23 т/га.

Висновки. Рівень урожайності зернобобових культур залежав від метеорологічних умов року, забур“яненості посіву і передпосівної інокуляції насіння. Найбільшим він був у 2015 р., де середня врожайність гороху, нуту і сої становила 1,74; 1,90 і 1,57 т/га відповідно. В забур“янених контролях найбільшу врожайність сформував нут, який виявився більш конкурентноздатним щодо бур“янів, ніж горох і соя. У цілому горох і нут формували найбільшу врожайність на фоні досходового застосування гербіциду Пульсар 40, а соя - післясходового. Приріст урожайності зернобобових культур від інокуляції виявлено майже на всіх варіантах досліду. Найбільшим він був на фоні досходового внесення гербіциду Пульсар 40 у посівах нуту $(0,12$ т/га).

Найвищою серед культур була соя, а найнижчим - горох. За досходового внесення гербіциду Пульсар 40 виявлено незначну тенденцію до зростання висоти культурних рослин, а післясходового - до зниження висоти прикріплення нижнього боба. Горох формував найменшу кількість продуктивних вузлів і бобів на одній рослині, а також кількість і масу насіння з рослини та масу однієї рослини; нут - кількість бобів у продуктивному вузлі та насіння в бобі; соя - масу 1000 насінин. Доказове зниження маси 1000 насінин виявлено в гороху і нуту на фоні без інокуляції під впливом післясходового застосування гербіциду Пульсар 40.

Вміст білка й олії в насінні гороху, нуту і сої істотно різнився в окремі роки досліджень. Найбільшими ці показники, а також їх збір, були в сої. Виявлено тенденцію до збільшення вмісту білка в насінні гороху за внесення гербіциду Пульсар 40 у період вегетації. Не виявлено істотного впливу комплексу досліджуваних факторів на вміст олії в насінні гороху, нуту і сої.

\section{Список використаних джерел}

1. Рожков А.О., Огурцов С.М. Рослинництво. Харків: Тім Пабліш Груп, 2017. 363 с.

2. Вус Н.О., Безугла О.М. Порівняльна характеристика зернобобових культур за посухостійкістю в зоні східного Лісостепу України. Матер. Міжнар. наук.-практ. конф. молодих вчених «Інноваційні напрями розвитку галузі рослинництва», 7-8 липня 2016 p. Харків: НТМН, 2016. С. 30-31.

3. Огурцов Ю.Є., Рогуліна Л.В. Вплив добрив на урожайність та збір білка сортів гороху різного морфо типу. Корми і кормовиробництво. 2006. Вип. 57. С. 162-166.

4. Кушнір О. М. Оцінка показників якості зерна гороху залежно від впливу технологічних прийомів. Корми і кормовиробництво. 2005. Вип. 55. С. 121-128. 
5. Плотніков В.В., Гильчук В.Г., Гуменний М.Б. Урожайність та якість зерна гороху при комплексному застосуванні системи агрохімікатів в сучасних конкурентоспроможних технологіях його вирощування. Корми і кормовиробництво. 2008. Вип. 62. С. 155-163.

6. Вус Н.О., Безугла О.М., Кобизєва Л.Н. Мінливість вмісту білка у колекційних зразків нуту в умовах Східного Лісостепу України. Корми і кормовиробництво. 2015. Вип. 82. C. 34-38.

7. Пасічник С.M., Січкар В.I. Біохімічні та технологічні якості колекційних зразків нуту. Селекція і насінництво. 2016. Вип. 110. С. 162-170.

8. Нецветаев В.П., Тютюнов С.И., Правдин И.В., Петренко А.В.Нут - перспективная бобовая культура в условиях изменения климата Юго-Запада ЦЧР РФ. Зернобобовые и крупяные культуры. 2016. № 2 (18). С. 137-143.

9. Jukanti A., Guar P., Gowda C., Chibbar R. Nutritional quality and health benefits of chickpea. Br. J. Nutr. 2012. № 108. P. 11-26.

10. Господаренко Г.М., Прокончук С.В. Вплив удобрення та інокуляції на показники якості зерна нуту. Збірник наукових праць Уманського національного університету садівництва. 2013. Вип. 83. Ч. 1 Агрономія. С. 12-19.

11. Каленська С.М., Новицька Н.В., Рожко В.І., Малинка Л.В., Барзо І.Т. Поліпшення посівних якостей насіння нуту за допомогою наночастинок біогенних металів. Збірник наукових праць Уманського національного університету садівництва. 2014. Вип. 85. Ч. 1 Агрономія. С. 79-84.

12. Гутянський Р.А. Особливості біохімічного складу насіння сортів сої з різною тривалістю вегетаційного періоду залежно від забур'яненості посіву. Селекція і насінництво. 2010. Вип. 98. С. 264-269.

13. Гутянський Р.А., Матвієць В.Г., Ільченко Н.К., Шелякіна Т.А., Матвієць Н.М. Вміст білка й олії в насінні сої, вирощеного на фоні застосування гербіцидів. Селекція і насінництво. 2012. Вип. 101. С. 223-229.

14. Григор'єва О.М. Урожайність та якість зерна сої залежно від обробітку грунту, удобрення та біопрепаратів в умовах північного Степу України. Сільськогосподарська мікробіологія. 2013. Вип. 17. С. 138-147.

15. Леонова Н.О., Титова Л.В., Танцюренко О.В., Антипчук А.Ф., Іутинська Г.О. Ефективність застосування нітрагіну і регуляторів росту рослин при вирощуванні сої. Сільськогосподарська мікробіологія. 2007. Вип. 5. С. 74-85.

16. Чорна В.М. Насіннєва продуктивність сої залежно від технологічних прийомів вирощування в умовах Лісостепу Правобережного. Корми і кормовиробництво. 2015. Вип. 82. С. 69-77.

17. Перелік пестицидів і агрохімікатів, дозволених до використання в Україні. Пропозиція нова. 2012. Спец. Випуск. 831 с.

\section{References}

1. Rozhkov AO, Ogurtsov YeM. Plant Production. Kharkiv: Tim Pablich grup, 2017. 363 p.

2. Vus NO, Bezugla OM. Comparative characterization of grain legumes for drought tolerance in the eastern Forest-Steppe of Ukraine. Materials of International Scientific Conference of Young Scientists «Innovative directions of plant growing development». Kharkiv, 2016 July 7-8. Plant Production Institute nd. a. V.Ya. Yuriev. Kharkiv: NTMN, 2016. P. 30-31.

3. Ogurtsov YuYe, Rogulina LV. Effect of fertilizers on the yield and protein output of pea varieties belonging to different morphotypes. Kormy i kormovyrobnytstvo. 2006; 57: 162-166.

4. Kushnir OM. Evaluation of pea grain quality parameters depending on technological methods. Kormy i kormovyrobnytstvo. 2005; 55: 121-128.

5. Plotnikov VV, Gilchuk VG, Gumenniy MB. Pea grain yield and quality upon complex application of agrochemicals in modern competitive technologies of its cultivation. Kormy $\mathrm{i}$ kormovyrobnytstvo. 2008; 62: 155-163. 
6. Vus NO, Bezugla OM, Kobyzeva LN. Variability of protein content in collection chickpea accessions in the eastern Forest-Steppe of Ukraine. Kormy i kormovyrobnytstvo. 2015; 82: 34-38.

7. Pasichnyk SM, Sichkar VI. Biochemical and technological qualities of chikrea collection accessions. Sel. nasinn. 2016; 110: 162-170.

8. Netsvitayev VP, Tiutiunov SI, Pravdin IV, Petrenko AV. Chickpea - a promising legume under climatic changes in the Southwest of the Central Black Earth Region of the Russian Federation. Zernobobovyie i krupianyie kultury. 2016; 2 (18): 137-143.

9. Jukanti A, Guar P, Gowda C, Chibbar R. Nutritional quality and health benefits of chickpea. Br. J. Nutr. 2012. 108: 11-26.

10. Gospodarenko GM, Prokopchuk SV. Effect of fertilization and inoculation on grain quality parameters. Zbirnyk naukovykh prats Umanskogo Natsionalnogo Universytetu sadivnytstva. 2013; 83 (1): 12-19.

11. Kalenska SM, Novitska NV, Rozhko VI, Malinka LV, Barzo IT. Improvement of sowing qualities of chickpea seeds using nanoparticles of biogenic metals. Zbirnyk naukovykh prats Umanskogo Natsionalnogo Universytetu sadivnytstva. 2014; 85 (1): 79-84.

12. Gutyanskiy RA. Peculiarities of biochemical composition of seeds of soybean varieties with various lengths of the growing season, depending on weediness. Sel. nasinn. 2010; 98: 264-269.

13. Gutyanskiy RA, Matviets VG, Ilchenko NK, Sheliakina TA, Matviets NM. Protein and oil contents in soybean seeds grown on herbicide application. Sel. nasinn. 2012; 101: 223-229.

14.Grigoryeva OM. Soybean grain yield and quality depending on tillage, fertilizers and bioagents in the northern Steppe of Ukraine. Silskogospodarska mikrobiologia. 2013; 17: 138-147.

15. Leonova NO, Titova LV, Tantsyurenko OV, Antipchuk AF, Iutinska GO. Efficiency of Nitragin and plant growth regulators for soybean cultivation. Silskohospodarska mikrobiologia. 2007; 5: 74-85.

16. Chorna VM. Soybean seed productivity depending on technological methods of cultivation in the Right-Bank Forest-Steppe. Kormy i kormovyrobnytstvo. 2015; 82: 69-77.

17. The list of pesticides and agrochemicals approved for use in Ukraine. Propozitsia nova. 2012; Special issue: 831 .

\section{УРОЖАЙНОСТЬ И КАЧЕСТВО СЕМЯН ГОРОХА, НУТА, СОИ ПРИ ВЛИЯНИИ ЗАСОРЕННОСТИ, ИНОКУЛЯЦИИ И ГЕРБИЦИДА}

Гутянский Р.А., Ильченко Н.К., Шелякина Т.А., Посылаева О.А.

Институт растениеводства им. В.Я. Юрьева НААН, Украина

Цель и задачи исследований. Определить комплексное влияние инокуляции семян гороха, нута, сои и разных сроков внесения гербицида Пульсар 40 на их урожайность и качество семян в условиях восточной части Лесостепи Украины.

Материалы и методика. В 2013-2015 гг. проводили исследования по следующей схеме: 1) культура (горох, нут, соя); 2) вариант обработки семян препаратом Ризобофит (без инокуляции, с инокуляцией); 3) вариант защиты от сорняков (контроль; Пульсар 40, 0,8 л/га до всходов; Пульсар 40, 0,8 л/га после всходов).

Обсуждение результатов. Уровень урожайности культур зависел от метеорологических условий года, засоренности посева и инокуляции семян. Наибольшим он был в 2015 г., когда средняя урожайность гороха, нута и сои составляла 1,74; 1,90 и 1,57 т/га соответственно. В контролях наивысшую урожайность формировал нут, проявляющий большую конкурентоспособность к сорнякам, чем горох и соя. В целом горох и нут сформировали наивысшую урожайность на фоне довсходового применения гербицида Пульсар 40 , а соя - послевсходового. Прирост урожайности культур от инокуляции выявлен в большинстве вариантов опыта, а наивысшим он был на фоне довсходового внесения гербицида в посевах нута $(0,12$ т/га). 
При довсходовом внесении гербицида выявлена тенденция к увеличению высоты культурных растений, а послевсходовом - к снижению высоты прикрепления нижнего боба. Горох формировал наименьшее количество продуктивных узлов и бобов на одном растении, а также количество и массу семян с растения и массу одного растения; нут - количество бобов в продуктивном узле и семян в бобе; соя - массу 1000 семян. Достоверное снижение массы 1000 семян гороха и нута на фоне без инокуляции установлено при послевсходовом внесении гербицида.

Содержание белка и жира в семенах существенно различалось в годы исследований. Наибольшими эти показатели были у сои. Выявлена тенденция к снижению содержания белка в семенах гороха при внесении гербицида в период вегетации. Не выявлено влияния изучаемых факторов на содержание жира в семенах.

Выводы. Гербицид Пульсар 40 - наиболее пригодный для посевов сои. Его послевсходовое применение в посевах гороха и нута на фоне без инокуляции достоверно снижало массу 1000 семян. Наибольший прирост урожайности от инокуляции семян препаратом Ризобофит выявлен на нуте. Не выявлено достоверного влияния изучаемых факторов на содержание белка и жира в семенах.

Ключевые слова: горох, нут, соя, инокулячия, сорняк, гербицид, урожайность, масса 1000 семян, белок, жир

\section{PEA, CHICKPEA AND SOYBEAN YIELDS AND QUALITY OF SEEDS UNDER THE INFLUENCE OF WEEDINESS, INOCULATION AND HERBICIDE}

Hutianskyi R.A., Ilchenko N.K., Sheliakina T.A., Posylaieva O.A.

Plant Production Institute nd. a. V.Ya. Yuriev of NAAS, Ukraine

The aim and tasks of the study. To determine the complex effect of inoculation of pea, chickpea and soybean seeds and different dates of application of herbicide Pulsar 40 on the yields and quality of seeds in the eastern Forest-Steppe of Ukraine.

Materials and methods. The 2013-2015 study design was as follows: 1) crop (pea, chickpea, soybean); 2) seed treatment with agent Rizobophyte (no inoculation, inoculation); 3) protection against weeds (control; Pulsar 40, 0.8 L/ha before emergence; Pulsar 40, $0.8 \mathrm{~L} / \mathrm{ha}$ after emergence).

Results and discussion. The crop yields depended on the meteorological conditions, weediness and inoculation of seeds. The greatest yields were obtained in 2015, when the average yield of pea, chickpea and soybean was $1.74,1.90$ and $1.57 \mathrm{t} / \mathrm{ha}$, respectively. In control, the greatest yield was produced by chickpea, which showed greater competitiveness to weeds than pea and soybean. In general, pea and chickpea gave the highest yields after pre-emergence application of herbicide Pulsar 40, and soybean - after post-emergence application. Gains in the crop yields from inoculation were recorded in most of the experiments, and the highest gain $(0.12$ $\mathrm{t} / \mathrm{ha}$ ) was achieved in chickpea after pre-emergence application of Pulsar 40.

With pre-emergence application of Pulsar 40, an upward tendency in the domestic plant height was observed, and post-emergence application was associated with a decrease in the lowest pod height. Pea had the smallest numbers of productive nodes and pods per plant as well as the seed number and weight per plant and the one-plant weight; chickpea had the smallest numbers of pods per productive node and of seeds per pod; soybean had the lowest 1000-seed weight. A significant decrease in the 1000 seed weight was detected for pea and chickpea without inoculation and with post-emergence application of Pulsar 40.

The protein and fat contents in seeds considerably varied in the study years. They were the highest in soybean. There was a downward tendency in the protein content in pea seeds, when Pulsar 40 was applied during the growing season. The factors under investigation did not affect the fat content in seeds. 
Conclusions. Herbicide Pulsar 40 is the most suitable for soybean. Post-emergence application of Pulsar 40 in pea and chickpea crops without inoculation significantly reduced the 1000 -seed weight. The greatest gain in the yield from seed inoculation with Rizobophyte was achieved in chickpea. There was no significant effect of the factors under investigation on the protein and fat contents in seeds.

Key words: pea, chickpea, soybean, inoculation, weeds, herbicide, yield, 1000-seed weight, protein, fat

Shyianova T.P., Tymchuk S.M., Boguslavskyi RL.

Plant Production Institute nd. a V.Ya. Yuriev of NAAS, Ukraine

According to the reaction of morphological parameters of seedlings from the grains of maize endospermal mutants to the influence of the regimes that simulate a longterm storage accelerated aging, freezing and combined regimes, the highest longevity is distinguished by ssp. indentata seeds, as well as carriers of the genes $a e$ and $s u_{1}$, low durability - carriers of the genes $w x$ and se, and the lowest - carriers of the gene $s h_{2}$.

Key words: maize, seeds, seedlings, morphology, endospermal mutants, longevity, accelerated aging, freezing.

Introduction. The progress in the breeding of maize which is one of the leading grain crops in the world, is associated with genetic regulation of the endosperm composition and structure. This enables fuller utilizing the wide potential of this crop as a source of raw materials for different industries and consumption areas, especially taking into account that endosperm structure mutations are natural and their use is not connected with overcoming legislative restrictions and human prejudices $[1,2,3]$. The $w x$ endosperm mutation carriers starch of which consists almost entirely of amylopectin, ae mutants which are characterized by significantly increased proportion of amylose in starch, $s u_{l}$ mutants with increased content of water-soluble polysaccharides in the endosperm, se mutants with increased contents of water-soluble polysaccharides and sucrose and $s h_{2}$ mutants which are characterized with very high content of sucrose in grain, are the most actively used $[4,5]$. However, in Ukraine, the effects of endosperm mutations are not properly used in crop and breeding practices. Insufficient longevity of stored seeds of endosperm mutants compared to traditional dent and flint forms is among the reasons for this. Therefore, not only the creation of such maize lines, but also their storage in collections of breeding institutions and genetic banks providing preservation of high sowing qualities of stored seeds is gaining importance.

Literary review, problem formulation. It is known from literature that seeds of endosperm mutants are often less long-living upon storage give weaker sprouts compared to seeds of traditional dent and flint forms [6]. This is particularly clearly evident in the $s h_{2}$ endosperm mutation carriers [7, 8] germinating under stress conditions [9]. It was established that reduced germination intensity of forms carrying this mutation or other mutations can be increased by selection $[10,11]$. This is in good agreement with some authors' conclusions about hereditary control of seed longevity and germination intensity [12].

(C) T.P. Shyianova, S.M. Tymchuk, RL. Boguslavskyi. 2018. ISSN 1026-9959. Селекція і насінництво. 2018. Випуск 113. 